\title{
Changes in Electric Properties of Human Breast Cancer Cells
}

\author{
Izabela Dobrzyńska $\cdot$ Elżbieta Skrzydlewska $\cdot$ \\ Zbigniew A. Figaszewski
}

Received: 17 July 2012/ Accepted: 15 October 2012/Published online: 8 November 2012

(C) The Author(s) 2012. This article is published with open access at Springerlink.com

\begin{abstract}
Studies of the electrical surface properties of biological cells have provided fundamental knowledge about the cell surface. The change in biological functions of cells may affect the surface properties and can be detected by electrokinetic measurements. The surface density of fibroblasts and breast cancer cells (MDAMB-231 and MCF-7) as a function of $\mathrm{pH}$ was measured by electrophoresis. The interaction between solution ions and the breast cancer cell or fibroblast surface was described by a four-component equilibrium model. The agreement between the experimental and theoretical charge variation curves of the breast cancer cells and fibroblasts was good at $\mathrm{pH} 2.5-9$. The extent of fibroblast and breast cancer cell lipid peroxidation was estimated by HPLC measurement of the malondialdehyde level. The acid $\left(C_{\mathrm{TA}}\right)$ and basic $\left(C_{\mathrm{TB}}\right)$ functional group concentrations and the average association constant with hydroxyl $\left(K_{\mathrm{BOH}}\right)$ ions values of the breast cancer cell membranes were higher than in normal cells, while the average association constant with hydrogen $\left(K_{\mathrm{AH}}\right)$ value was smaller. The level of lipid peroxidation products was higher in breast cancer cells than in normal cells.
\end{abstract}

I. Dobrzyńska $(\bowtie) \cdot$ Z. A. Figaszewski

Institute of Chemistry, University in Białystok,

Al. Piłsudskiego 11/4, 15-443 Białystok, Poland

e-mail: izadob@uwb.edu.pl

E. Skrzydlewska

Department of Analytical Chemistry, Medical University

of Białystok, Mickiewicza 2, 15-230 Białystok, Poland

\section{Z. A. Figaszewski}

Laboratory of Electrochemical Power Sources, Faculty of

Chemistry, University of Warsaw, Pasteur St. 1,

02-093 Warsaw, Poland
Keywords Surface charge density - Breast cancer cell (MDA-MB-231 · MCF-7) · Fibroblast · Lipid peroxidation

\section{Introduction}

The electric charge of cell membranes of mammals is negative at physiological pH (Benga and Holmes 1984). Conservation of membrane structure and of its proper surface charge is crucial in processes in which the membrane is involved. Among them the most important are transport of metabolism substrates and products by ion pumps, membrane carriers and channels as well as information transmission (Nałęcz 1989).

Any perturbation in the action of the cell is manifested by variations in the action of the cell membrane, i.e., in its electric layer. An essential property of the electric double layer is its electric charge, which can be altered by various xenobiotics or by metabolic transformations. For this reason, studies of electric charge can furnish much information on the equilibrium existing within the membrane and between the membrane and its environment, both in physiological and in nonphysiological conditions (Szachowicz-Petelska et al. 2012; Gennis 1989; Dołowy 1984). Cell membrane charge increases during tumorigenesis and decreases during necrosis (Dołowy 1984). Determining the electric charge of the membrane as a function of environmental $\mathrm{pH}, \operatorname{acid}\left(C_{\mathrm{TA}}\right)$ and basic $\left(C_{\mathrm{TB}}\right)$ functional group concentrations and their average association constants with hydrogen $\left(K_{\mathrm{AH}}\right)$ or hydroxyl $\left(K_{\mathrm{BOH}}\right)$ ions allows monitoring of changes caused by cancer transformation (Dobrzyńska et al. 2006).

It is well known that malignant neoplastic cells are different in their surface properties from their normal counterparts. Unusual cell-to-cell interactions in malignant 
cells are the most important behavior for distinguishing them from their normal counterparts and for determining the prognosis of patients suffering from cancer.

This work continues the study of electrical property changes of cell membranes under the influence of cancer transformation (Dobrzyńska et al. 2005; SzachowiczPetelska et al. 2010). We examined changes in the electric charge of cell membranes caused by cancer transformation in an in vitro study.

Cancerous cell lines are an excellent way for examining the mechanisms of carcinogenesis, and research using vitro cultures is bringing significant benefit. Therefore, the purpose of this work was to determine the electrical properties of the membrane and the level of lipid peroxidation products of human breast cancer cells (MDA-MB-231 and MCF-7) and normal cells (fibroblasts). In our opinion, the quantitative description of cell membrane surface properties can help in interpreting and understanding the processes that take place on biological membrane surfaces during cancer transformation.

\section{Theory}

The model, which has been presented in full detail in a previous study (Dobrzyńska et al. 2006), assumes that the dependence of the surface charge density of the cell membrane on the $\mathrm{pH}$ of an electrolyte solution can be described with the help of four equilibria. There are two equilibria of negative groups, with sodium and hydrogen ions, and two equilibria of the positive groups, with hydroxide and chloride ions. $\mathrm{H}^{+}, \mathrm{OH}^{-}, \mathrm{Na}^{+}$and $\mathrm{Cl}^{-}$ions are adsorbed at the cell membrane (fibroblasts, MDAMB-231, MCF-7), and the adsorption equilibria (Eqs. 1-4) can by presented in the following forms:

$$
\begin{aligned}
& A^{-}+\mathrm{H}^{+} \Leftrightarrow A \mathrm{H} \\
& A^{-}+\mathrm{Na}^{+} \Leftrightarrow A \mathrm{Na} \\
& B^{+}+\mathrm{OH}^{-} \Leftrightarrow B \mathrm{OH} \\
& B^{+}+\mathrm{Cl}^{-} \Leftrightarrow B \mathrm{Cl}
\end{aligned}
$$

The association constants of the $\mathrm{H}^{+}, \mathrm{Na}^{+}, \mathrm{OH}^{-}$and $\mathrm{Cl}^{-}$ ions with functional groups are expressed by the following equations:

$$
\begin{aligned}
K_{\mathrm{AH}} & =\frac{a_{\mathrm{AH}}}{a_{\mathrm{A}^{-}} \cdot a_{\mathrm{H}^{+}}} \\
K_{\mathrm{ANa}} & =\frac{a_{\mathrm{ANa}}}{a_{\mathrm{A}^{-}} \cdot a_{\mathrm{Na}^{+}}} \\
K_{\mathrm{BOH}} & =\frac{a_{\mathrm{BOH}}}{a_{\mathrm{B}^{+}} \cdot a_{\mathrm{OH}^{-}}}
\end{aligned}
$$

$K_{\mathrm{BCl}}=\frac{a_{\mathrm{BCl}}}{a_{\mathrm{B}^{+}} \cdot a_{\mathrm{Cl}^{-}}}$

where $K_{\mathrm{AH}}, K_{\mathrm{ANa}}, K_{\mathrm{BOH}}$ and $K_{\mathrm{BCl}}$ are association constants; $a_{\mathrm{A}^{-}}, a_{\mathrm{AH}}, a_{\mathrm{ANa}}, a_{\mathrm{B}^{+}}, a_{\mathrm{BOH}}$ and $a_{\mathrm{BCl}}$ are surface concentrations of the corresponding groups on the membrane surface; and $a_{\mathrm{H}^{+}}, a_{\mathrm{Na}^{+}}, a_{\mathrm{OH}^{-}}$and $a_{\mathrm{Cl}^{-}}$are the corresponding concentrations in solution.

Surface charge density $(\delta)$ is expressed as follows:

$\delta=\left(a_{\mathrm{B}^{+}}-a_{\mathrm{A}^{-}}\right) \cdot F$

where $F=96,487\left[\frac{C}{\mathrm{~mol}}\right]$ is the Faraday constant.

Functional group concentration balances are expressed as follows:

$C_{\mathrm{TA}}=a_{\mathrm{A}^{-}}+a_{\mathrm{AH}}+a_{\mathrm{ANa}}$

$C_{\mathrm{TB}}=a_{\mathrm{B}^{+}}+a_{\mathrm{BOH}}+a_{\mathrm{BCl}}$

where $C_{\mathrm{TA}}$ is the total surface concentration of acidic groups and $C_{\mathrm{TB}}$ is the total surface concentration of basic groups.

Elimination of $a_{\mathrm{A}^{-}}, a_{\mathrm{AH}}, a_{\mathrm{B}^{+}}$and $a_{\mathrm{BOH}}$ values from the above equation yields the following formula:

$$
\begin{aligned}
\frac{\delta}{F}= & \frac{C_{\mathrm{TB}} \cdot a_{\mathrm{H}^{+}}}{a_{\mathrm{H}^{+}}\left(1+K_{\mathrm{BCl}} \cdot a_{\mathrm{C}^{-}}\right)+K_{\mathrm{BOH}} \cdot K_{\mathrm{w}}} \\
& -\frac{C_{\mathrm{TA}}}{K_{\mathrm{AH}} \cdot a_{\mathrm{H}^{+}}+K_{\mathrm{ANa}} \cdot a_{\mathrm{Na}^{+}}+1},
\end{aligned}
$$

It is difficult to solve Eq. 12 and determine the $K_{\mathrm{AH}}$, $K_{\mathrm{ANa}}, K_{\mathrm{BOH}}$ and $K_{\mathrm{BCl}}$ constants. In cases of high or low hydrogen ion concentrations, Eq. 12 can be simplified to a linear equation. In the range of high $\mathrm{H}^{+}$concentrations, the numerator of each term in Eq. 12 can be divided by the denominator, leaving two initial terms only. These operations yield the linear equation in the $a_{\mathrm{H}^{+}}$and $\frac{\delta}{F} a_{\mathrm{H}^{+}}$ coordinate system:

$$
\begin{aligned}
\frac{\delta}{F} a_{\mathrm{H}^{+}}= & \frac{C_{\mathrm{TB}}}{1+K_{\mathrm{BCl}} \cdot a_{\mathrm{Cl}^{-}}} \cdot a_{\mathrm{H}^{+}} \\
& -\left(\frac{K_{\mathrm{BOH}} \cdot K_{\mathrm{w}} \cdot C_{\mathrm{TB}}}{\left(1+K_{\mathrm{BCl}} \cdot a_{\mathrm{Cl}^{-}}\right)^{2}}+\frac{C_{\mathrm{TA}}}{K_{\mathrm{AH}}}\right)
\end{aligned}
$$

In graphical representation, the slope and the intercept can be easily extracted. At low $\mathrm{H}^{+}$ion concentration Eq. 12 simplifies to

$$
\begin{aligned}
\frac{\delta}{F}= & \frac{C_{T B} \cdot a_{H^{+}}}{K_{B O H} \cdot K_{w}+a_{H^{+}}\left(1+K_{B C l} \cdot a_{C l^{-}}\right)} \\
& -\frac{C_{T A}}{K_{A N a} \cdot a_{N a^{+}}+1+K_{A H} \cdot a_{H^{+}}}
\end{aligned}
$$

The numerator of each term should be divided by the denominator, leaving two initial terms only. These operations yield a linear equation in the $a_{\mathrm{H}^{+}}^{-1}$ and $\frac{\delta}{F} a_{\mathrm{H}^{+}}^{-1}$ coordinate system: 


$$
\begin{aligned}
\frac{\delta}{F} a_{\mathrm{H}^{+}}^{1}= & \frac{-C_{\mathrm{TA}} \cdot a_{\mathrm{H}^{+}}^{-1}}{1+K_{\mathrm{ANa}} \cdot a_{\mathrm{Na}^{+}}} \\
& +\left(\frac{C_{\mathrm{TB}}}{K_{\mathrm{BOH}} \cdot K_{\mathrm{W}}}+\frac{K_{\mathrm{AH}} \cdot C_{\mathrm{TA}}}{\left(1+K_{\mathrm{ANa}} \cdot a_{\mathrm{Na}^{+}}\right)^{2}}\right)
\end{aligned}
$$

In graphical representation, the slope and the intercept can be easily extracted.

The coefficients estimated from linear regression can be used to determine $C_{\mathrm{TA}}, C_{\mathrm{TB}}, K_{\mathrm{AH}}$ and $K_{\mathrm{BOH}}$. The points included in the regression must be carefully selected, in both high and low $\mathrm{pH}$ ranges. Defining the value of these parameters permits the calculation of the theoretical cell membrane surface charge from Eq. 12 for comparison to experimental data.

\section{Materials and Methods}

\section{Cell Culture}

Normal human skin fibroblasts, CRL-1474, and two types of breast cancer cells, MCF-7 and MDA-MB-231 (derived by the American Type Culture Collection, Manassas, VA), were maintained in DMEM containing $10 \%$ fetal bovine serum, $50 \mathrm{U} / \mathrm{ml}$ penicillin and $50 \mu \mathrm{g} / \mathrm{ml}$ streptomycin in a humidified atmosphere of $5 \% \mathrm{CO}_{2}$ at $37{ }^{\circ} \mathrm{C}$. Suspension of cells $\left(1 \times 10^{6}\right.$ cells $\left./ \mathrm{ml}\right)$ in $6 \mathrm{ml}$ of culture medium were incubated with or without the test compounds in cell culture plates.

\section{Lipid Peroxidation}

The extent of lipid peroxidation in cells was assayed as malondialdehyde (MDA) levels. MDA level was estimated as a condensation product reaction of thiobarbituric acid (TBA) with MDA that was separated by HPLC. We added $0.75 \mathrm{ml}$ phosphate acid solution $(0.44 \mathrm{M})$ and $0.25 \mathrm{ml}$ freshly prepared TBA solution ( $42 \mathrm{mM})$ to $0.5 \mathrm{ml}$ diluted lysate cells, and the mixture was incubated for $60 \mathrm{~min}$ at $100{ }^{\circ} \mathrm{C}$. After cooling down, $0.5 \mathrm{ml}$ of the above mixture was neutralized with a $0.5-\mathrm{ml} 1 \mathrm{M}$ methanol-1 $\mathrm{M} \mathrm{NaOH}$ mixture (45.5:4.5, v:v). After centrifugation, $30 \mu \mathrm{l}$ of solution was injected in the chromatographic column (RP18). Separation was carried out with isocratic elution $(40 \%$ methanol and $60 \%$ phosphate buffer, $\mathrm{pH}$ 7.0). Detection with a spectrofluorimetric detector $\left(\lambda_{\text {excitation }}=532 \mathrm{~nm}\right.$, $\lambda_{\text {emission }}=553 \mathrm{~nm}$ ) was done. The concentration of MDA was expressed in nanomoles TBA-rs per milliliter cell lysate.

\section{Electrochemical Method}

In order to determine the surface charge density of cell membranes, cells were suspended in $0.015 \mathrm{M} \mathrm{NaCl}$ and put into the measuring vessel; then, electrophoretic mobility was measured using the Zetasizer Nano ZS apparatus (Malvern Instruments, Malvern, UK). Measurements were carried out as a function of $\mathrm{pH}$.

Surface charge density was determined using the equation $\sigma=\eta u / d$, where $u$ is electrophoretic mobility, $\eta$ is viscosity of solution and $d$ is diffuse layer thickness (Krysiński and Tien 1986).

The diffuse layer thickness was determined from the formula (Barrow 1996) $d=\sqrt{\frac{\varepsilon \varepsilon_{0} R T}{2 F^{2} I}}$, where $R$ is the gas constant, $T$ is the temperature, $F$ is the Faraday number, $I$ is the ionic strength of $0.9 \% \mathrm{NaCl}$ and $\varepsilon_{0}$ is the permeability electric medium.

Statistical Analysis

The data obtained in this study are expressed as mean $\pm \mathrm{SD}$. The data were analyzed using standard statistical analyses, one-way ANOVA with Scheffe's $F$ test for multiple comparisons to determine the significance between different groups. $p<0.05$ was considered significant.

\section{Results and Discussion}

Normal cells possess the ability to communicate information inside themselves and between other cells. The coordination of information by the cells of the body is involved in the regulation and integration of cellular functions and cell growth. When cancer arises, cancer cells are no longer regulated by the normal control mechanisms. Cancerous cells also possess other features that are different from normal proliferating cells. Normal cells are well organized in their growth, form strong contacts with their neighbors and stop growing when they repair the area of injury due to contact inhibition with other cells. Cancer cells are more easily detached and do not exhibit contact inhibition of their growth. Cancer cells become independent of normal tissue signaling and growth-control mechanisms. In a sense cancer cells become desynchronized from the rest of the body.

The surface charge density (experimental and theoretical) of the cell membrane as a function of $\mathrm{pH}$ are presented in Figs. 1 and 2. The former are indicated by points, and the latter are indicated by curves. It can be seen in the figures that the surface charge density dependence of MDA-MB cells, MCF-7 cells and fibroblasts on $\mathrm{pH}$ is similarly shaped for all studied cells. There is an increase in positive surface charge density of the cells at low $\mathrm{pH}$ values until a plateau is reached. At high $\mathrm{pH}$ values, the negative charge of the cells also increases, reaching a plateau. 


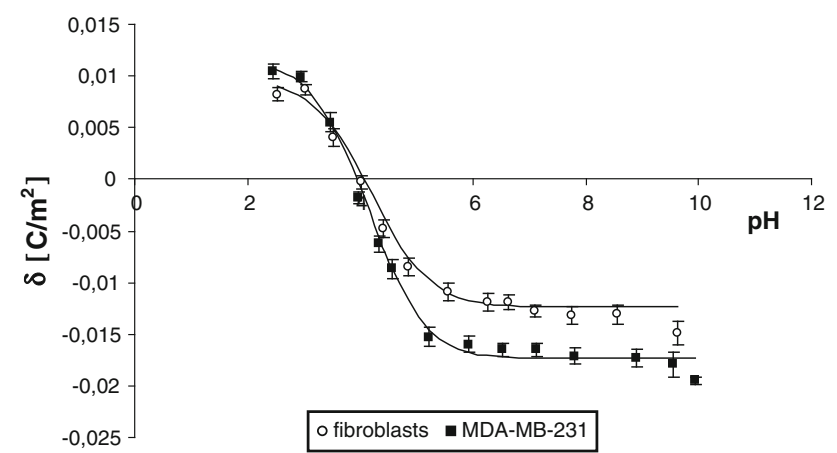

Fig. 1 Dependence of surface charge density of fibroblasts and breast cancer cell (MDA-MB-231) membranes on $\mathrm{pH}$ (experimental values are marked by points and theoretical ones by line)

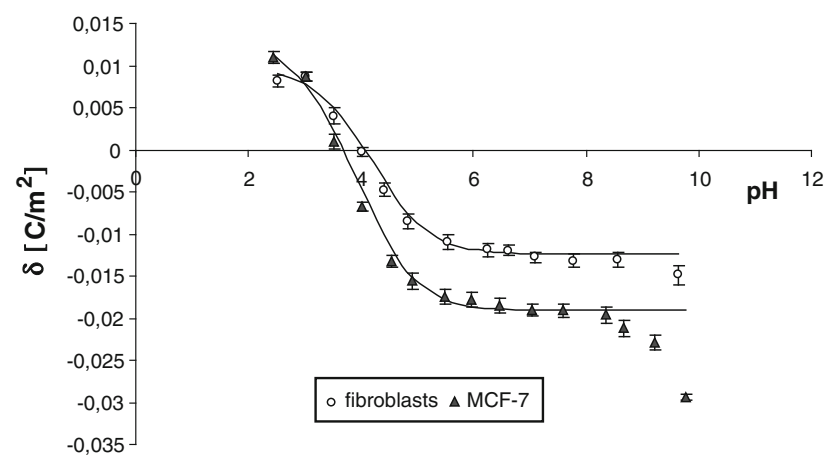

Fig. 2 Dependence of surface charge density of fibroblasts and breast cancer cell (MCF-7) membranes on $\mathrm{pH}$ (experimental values are marked by points and theoretical ones by line)

The negative charge at high $\mathrm{pH}$ values as well as the positive charge at low $\mathrm{pH}$ values of human breast cancer cells are higher than those in fibroblasts, with a shift of isoelectric point of the membrane to low $\mathrm{pH}$ values (Figs. 1, 2).

Mathematical calculations based on the four equilibria model (presented above, theory), describing adsorption of electrolyte ions on a cell membrane surface, enabled quantitative evaluation of the membrane characterizing parameters. The total concentrations of functional acidic $\left(C_{\mathrm{TA}}\right)$ and basic $\left(C_{\mathrm{TB}}\right)$ groups on breast cancer cell as well as fibroblast surfaces and their average association constants with hydrogen $\left(K_{\mathrm{AH}}\right)$ and hydroxyl $\left(K_{\mathrm{BOH}}\right)$ ions were calculated based on Eqs. 13 and 14. The $C_{\mathrm{TA}}, C_{\mathrm{TB}}$, $K_{\mathrm{AH}}$ and $K_{\mathrm{BOH}}$ constants resulting from determination were substituted into Eq. 12, yielding the theoretical curve. Typical experimental points and the theoretical curve are presented in Figs. 1 and 2. It can be observed that the theoretical and experimental surface charge density values agree. The $C_{\mathrm{TA}}, C_{\mathrm{TB}}$ and $K_{\mathrm{BOH}}$ values of the cell membranes modified by cancer transformation were higher than in normal cells, while the $K_{\mathrm{AH}}$ value was smaller (Table 1).

It has been demonstrated that cancer transformation causes modifications in the lipid bilayer membrane (Punnonen et al. 1989; Szachowicz-Petelska et al. 2012). An increase in the content of phospholipids is observed in human breast cancer cells (Sakai et al. 1992; Punnonen et al. 1989; Podo et al. 2007). Increased phospholipid content may result from enhanced cell membrane synthesis related to accelerated neoplasm cell replication (Ruiz-Cabello and Cohen 1992). Increased amount of phospholipids results in a higher amount of functional groups: amino, carboxy and phosphate groups. In acid medium (low $\mathrm{pH}$ ) the charge of phospholipids is mainly due to amino groups, whereas in basic medium (high $\mathrm{pH}$ ) it is due to carboxy and phosphate groups. Increased amount of phospholipids can increase the surface density of negatively charged groups of breast cancer cell membranes at high $\mathrm{pH}$ values and that of positively charged ones at low $\mathrm{pH}$.

Hypoxia/reoxygenation and acidity induced exposure of anionic phospholipids, most likely phosphatidylserine and phosphatidylethanolamine (Zhao et al. 1998; Ran et al. 2002). According to previous studies both hypoxia and acidity can exist in a tumor. In particular, hypoxia represents an important cellular stressor that can trigger a survival program by which cells attempt to adapt to a new environment. Typically, these adaptations will largely affect cell metabolism and/or stimulation of oxygen delivery (Bos et al. 2004).

Cell membrane charge is also affected by sialic acid present in glycolipids and glycoproteins. It has been supposed that sialic acid also influences the surface concentration of acid and basic groups as well as the association

Table $1 \mathrm{C}_{\mathrm{TA}}, \mathrm{C}_{\mathrm{TB}}, K_{\mathrm{AH}}$ and $K_{\mathrm{BOH}}$ of fibroblasts and breast cancer cells (MDA-MB-231, MCF-7) membranes

\begin{tabular}{lllll}
\hline Groups & \multicolumn{2}{l}{ Parameters } & & \\
\cline { 2 - 5 } & $C_{\mathrm{TA}}\left(10^{-7} \mathrm{~mol} / \mathrm{m}^{2}\right)$ & $C_{\mathrm{TB}}\left(10^{-7} \mathrm{~mol} / \mathrm{m}^{2}\right)$ & $K_{\mathrm{AH}}\left(\mathrm{m}^{3} / \mathrm{mol}^{2}\right)$ & $K_{\mathrm{BOH}}\left(10^{7} \mathrm{~m}^{3} / \mathrm{mol}^{2}\right)$ \\
\hline Fibroblasts & $1.23 \pm 0.08$ & $0.96 \pm 0.06$ & $32.80 \pm 0.90$ & $1.68 \pm 0.08$ \\
MCF-7 & $1.73 \pm 0.10^{*}$ & $1.16 \pm 0.09 *$ & $26.81 \pm 1.10^{*}$ & $2.92 \pm 0.12^{*}$ \\
MDA-MB-231 & $1.90 \pm 0.12^{*}$ & $1.31 \pm 0.10^{*}$ & $18.8 \pm 1.08^{*}$ & $4.97 \pm 0.18^{*}$ \\
\hline
\end{tabular}

$* p<0.05$, compared with fibroblasts 
Table 2 Levels of final lipid peroxidation product malondialdehyde (MDA, nmol/mg) in fibroblasts and breast cancer cells (MDAMB-231, MCF-7)

\begin{tabular}{lll}
\hline Fibroblasts & MDA-MB & MCF-7 \\
\hline $1.00 \pm 0.05$ & $1.39 \pm 0.04^{*}$ & $10.57 \pm 0.42^{*}$ \\
\hline
\end{tabular}

$* p<0.05$ compared with fibroblasts

constants of positive and negative groups during cancer transformation. Increased sialic acid content in glycolipids and glycoproteins has been confirmed by literature data (Narayanan 1994; Jakielaszek et al. 1986). Increased sialic acid content can provoke increased surface concentration of acid groups.

Table 2 shows changes in the level of final lipid peroxidation product MDA measured by HPLC as a TBA derivative. The level of MDA was significantly higher in breast cancer cells (MDA-MB-231, MCF-7) than in normal cells (Table 2).

Membrane lipids and proteins can also be modified by reactive oxygen species (ROS) appearing as the result of cancer transformation (Gago-Dominguez et al. 2007; Skrzydlewska et al. 2005). ROS provoke the so-called lipid peroxidation. As a consequence, phosphatidylserine molecules, physiologically present on the inner side of the membrane, become exposed on the outer side (Tyurina et al. 2000). Exposing the phosphatidylserine molecule to the outer side of the membrane makes an additional negatively charged group appear there. It provokes an increase in acid group surface concentration, as confirmed in this work (Table 1). The presence of additional functional groups of phosphatidylserine can result in a decreased association constant of negatively charged groups of the membrane and an increased association constant of positively charged ones because the $K_{\mathrm{AH}}$ value is lower and the $K_{\mathrm{BOH}}$ value is higher than those of the original cell membrane groups (Dobrzyńska et al. 2007).

The reaction of aldehydes produced during lipid peroxidation with amino acid residues of proteins might lead to their oxidative modification. In this process, the final products of lipid peroxidation, such as MDA as well as other products resulting from polyunsaturated fatty acid damage, could cause protein breakdown (Esterbauer et al. 1991).

The ultimate consequence of oxidative modification of proteins can be their aggregation or fragmentation (Davies et al. 1987; Du and Gebicki 2002). Protein fragmentation creates increasing functional groups, both acidic and basic. The process can also expose membrane phospholipid functional groups hitherto screened by proteins. The changes can yield higher $C_{\mathrm{TA}}$ values and lower $C_{\mathrm{TB}}$ values, as confirmed by this work.

The data suggest that the electrical properties of breast cancer cells are different from those of normal cells. The constants $C_{\mathrm{TA}}, C_{\mathrm{TB}}, K_{\mathrm{AH}}$ and $K_{\mathrm{BOH}}$ are suited for monitoring the changes caused by cancer transformation. Therefore, an evaluation of the parameters characterizing cancer cell membranes may be an important consideration in future studies of cancer biology.

Acknowledgments This work was supported by a grant from the Polish Committee of Scientific Research (NN405268837).

Open Access This article is distributed under the terms of the Creative Commons Attribution License which permits any use, distribution, and reproduction in any medium, provided the original author(s) and the source are credited.

\section{References}

Barrow GM (1996) Physical chemistry. McGraw-Hill, New York

Benga G, Holmes RP (1984) Interactions between components in biological membranes and their implications for membrane function. Prog Biophys Mol Biol 43:195-257

Bos R, van Diest PJ, van der Groep P, Shvarts A, Greijer AE, van der Wall E (2004) Expression of hypoxia-inducible factor- $1 \alpha$ and cell cycle proteins in invasive breast cancer are estrogen receptor related. Breast Cancer Res 6:R450-R459

Davies KJA, Delsignore ME, Lin SW (1987) Protein damage and degradation by oxygen radicals. II. Modification of amino acids. J Biol Chem 262:9902-9907

Dobrzyńska I, Szachowicz-Petelska B, Figaszewski Z, Sulkowski S (2005) Changes in electric charge and phospholipid composition in human colorectal cancer cells. Mol Cell Biochem 276:113-119

Dobrzyńska I, Skrzydlewska E, Figaszewski Z (2006) Parameters characterizing acid-base equilibria between cell membrane and solution and their application to monitoring the effect of various factors on the membrane. Bioelectrochemistry 69:142-147

Dobrzyńska I, Kotyńska J, Figaszewski Z (2007) Changes in electrical charge of phosphatidylcholine and phosphatidylserine liposomal membranes caused by adsorption of monovalent ions. Chem Anal 52:931-944

Dołowy K (1984) Bioelectrochemistry of cell surface. Prog Surf Sci 15:245-368

Du J, Gebicki JM (2002) DNA degradation and protein peroxidation in cells exposed to hydroxyl free radicals. Redox Rep 7:329-331

Esterbauer H, Schaur RJ, Zollner J (1991) Chemistry and biochemistry of 4-hydroxy-nonenal, malondialdehyde and related aldehydes. Free Radic Biol Med 11:81-128

Gago-Dominguez M, Jiang X, Castelao JE (2007) Lipid peroxidation, oxidative stress genes and dietary factors in breast cancer protection: a hypothesis. Breast Cancer Res 9:201-211

Gennis RB (1989) Biomembranes: molecular structure and functions. Springer-Verlag, New York

Jakielaszek JM, Madej JA, Sobiech KA (1986) Glycoproteins and sialoproteins in the serum and internal organs of mice with transplantable leukemia. Pollut Arch Water 26:95-105

Krysiński P, Tien HY (1986) Membrane electrochemistry. Prog Surf Sci 23:17-412

Nałęcz KA (1989) Functional and structural aspects of transport of low molecular weight compounds through biological membranes. Post Biochem 35:437-467

Narayanan S (1994) Sialic acid as a tumor marker. Ann Clin Lab Sci 24:376-384

Podo F, Sardanelli F, Iorio E, Canese R, Carpinelli G, Fausto A, Canevari S (2007) Abnormal choline phospholipid metabolism 
in breast and ovary cancer: molecular bases for noninvasive imaging approaches. Curr Med Imaging Rev 3:123-137

Punnonen K, Hietanen E, Auvinen O, Punnonen R (1989) Phospholipids and fatty acid in breast cancer tissue. J Cancer Res Clin Oncol 115:575-578

Ran S, Downes A, Thorpe PE (2002) Increased exposure of anion phospholipids on the surface of tumor blood vessels. Cancer Res 62:6132-6140

Ruiz-Cabello J, Cohen JS (1992) Phospholipids metabolites as indicators of cancer cell function. NMR Biomed 5:226-233

Sakai K, Okuyama H, Yura J, Takeyama H, Shinagawa N, Tsuruga N, Kato K, Miura K, Kawase K, Tsujimura T, Naruse T, Koike A (1992) Composition and turnover of phospholipids and neutral lipids in human breast cancer and reference tissues. Carcinogenesis 13:579-584

Skrzydlewska E, Sulkowski S, Koda M, Zalewski B, Kanczuga-Koda L, Sulkowska M (2005) Lipid peroxidation and antioxidant status in colorectal cancer. World J Gastroenterol 11:403-406
Szachowicz-Petelska B, Dobrzyńska I, Sulkowski S, Figaszewski Z (2010) Characterization of the cell membrane during cancer transformation. J Environ Biol 31:845-850

Szachowicz-Petelska B, Dobrzyńska I, Sulkowski S, Figaszewski ZA (2012) Characterization of the cell membrane during cancer transformation. In: Ettarh R (ed) Cancer biology-from genes to tumor. InTech, Rijeka, Croatia, pp 241-256

Tyurina YY, Shvedova AA, Kawai K, Tyurin VA, Kommineni C, Quinn PJ, Schor NF, Fabisiak JP, Kagan VE (2000) Phospholipid signaling in apoptosis: peroxidation and externalizotion of phosphatidylserine. Toxicology 148:93-101

Zhao J, Zhou Q, Wiedmer T, Sims PJ (1998) Level of expression of phospholipid scramblase regulates induced movement of phosphatidylserine to the cell surface. J Biol Chem 273:6603-6606 